\title{
West syndrome: a comprehensive review
}

\section{Piero Pavone $^{1} \cdot$ Agata Polizzi $^{2}$ - Simona Domenica Marino ${ }^{3} \cdot$ Giovanni Corsello $^{4} \cdot$ Raffaele Falsaperla $^{4} \cdot$ Silvia Marino $^{3}$. Martino Ruggieri ${ }^{5}$ (I)}

Received: 7 December 2019 / Accepted: 14 July 2020 / Published online: 22 August 2020

(C) The Author(s) 2020

\begin{abstract}
Since its first clinical description (on his son) by William James West (1793-1848) in 1841, and the definition of the classical triad of (1) infantile spasms; (2) hypsarrhythmia, and (3) developmental arrest or regression as "West syndrome", new and relevant advances have been recorded in this uncommon disorder. New approaches include terminology of clinical spasms (e.g., infantile (IS) vs. epileptic spasms (ES)), variety of clinical and electroencephalographic (EEG) features (e.g., typical ictal phenomena without EEG abnormalities), burden of developmental delay, spectrum of associated genetic abnormalities, pathogenesis, treatment options, and related outcome and prognosis. Aside the classical manifestations, IS or ES may present with atypical electroclinical phenotypes (e.g., subtle spasms; modified hypsarrhythmia) and may have their onset outside infancy. An increasing number of genes, proteins, and signaling pathways play crucial roles in the pathogenesis. This condition is currently regarded as a spectrum of disorders: the so-called infantile spasm syndrome (ISs), in association with other causal factors, including structural, infectious, metabolic, syndromic, and immunologic events, all acting on a genetic predisposing background. Hormonal therapy and ketogenic diet are widely used also in combination with (classical and recent) pharmacological drugs. Biologically targeted and gene therapies are increasingly studied. The present narrative review searched in seven electronic databases (primary MeSH terms/keywords included West syndrome, infantile spasms and infantile spasms syndrome and were coupled to 25 secondary clinical, EEG, therapeutic, outcomes, and associated conditions terms) including MEDLINE, Embase, Cochrane Central, Web of Sciences, Pubmed, Scopus, and OMIM to highlight the past knowledge and more recent advances.
\end{abstract}

Keywords West syndrome $\cdot$ Infantile spasms $\cdot$ Epileptic spasms $\cdot$ Infantile spasms syndrome $\cdot$ Etiology $\cdot$ Genetics

Martino Ruggieri

m.ruggieri@unict.it

1 Unit of Clinical Pediatrics, AOU "Policlinico", PO "G. Rodolico", University of Catania, Catania, Italy

2 Chair of Pediatrics, Department of Educational Sciences, University of Catania, Catania, Italy

3 Unit of Pediatrics, Neonatology and Neonatal Intensive Care, and Pediatric Emergency, AOU "Policlinico", PO "San Marco", University of Catania, Catania, Italy

4 Unit of Pediatrics and Neonatal Intensive Therapy, Department of Promotion of Maternal and Infantile and Internal Medicine Health, and Specialist Excellence “G. D'Alessandro", University of Palermo, Palermo, Italy

5 Unit of Rare Diseases of the Nervous System in Childhood, Department of Clinical and Experimental Medicine, Section of Pediatrics and Child Neuropsychiatry, University of Catania, AOU "Policlinico", PO "G. Rodolico", Via S. Sofia, 87, 95128 Catania, Italy

\section{Introduction}

An increasing and changeable number of terms, on the disorder first reported by William James West (1793-1848) on his own son James Edwin (1840-1860) in 1841 [1], and subsequently labeled as "West syndrome" (WS), have been progressively proposed, first adopting the term infantile spasms (IS) in accordance with the most relevant clinical event, and later the term epileptic spasms (ES), since the disorder may have its onset outside infancy $[2,3]$.

The classical terms WS and IS are still the most quoted in the literature and, concordantly, the term ES has been incorporated within the umbrella definition of "infantile spasms syndrome" (ISs), as the different seizure types, the EEG and developmental features tend to occur all together and at the same time $[4,5]$. The ISs belongs to the group of "early epileptic encephalopathies" (EEE), characterized by severe, drug-resistant epileptic disorders, with onset in early life, associated to persistent EEG abnormalities and cognitive 
defects. By definition, in this group of disorders, the seizures per se may contribute, above and beyond the causal effects, to the progression of cerebral dysfunction [5-8]. The ictal phenotype is the result of a cellular/molecular cascade of events, which in turn is responsible for the neurodevelopmental abnormalities. The ictal phenomenon, without associated EEG abnormalities, has been reported [9]. In several reports West syndrome, infantile spasms, epileptic spasms, and infantile spasms syndrome (WS, IS, ES and ISs) are still used interchangeably. In this report, we prefer to use the term "IS" to indicate the ictal phenomenon and the term "ISs" to describe the (spectrum of) disorder(s) associated to IS.

Over the last years, new advances in all the relevant and less common aspects of this uncommon disorder have been achieved including its nomenclature, etiology, associated genetic factors, variety of clinical features and complex phenotypes, and modalities of treatment and prognosis [7, 8].

The ISs is estimated to occur in about 0.249 cases/1000 live births [10] with an overall prevalence of $1 / 10,000$ children at the age of 10 years $[11,12]$. The number of affected children by this condition is consistent over time and no increase has been recorded in the most recent population-based and caseseries studies $[10,11]$. Both genders are affected by a relatively small prevalence of males.

In the present review article, we aimed to highlight the past knowledge and more recent advances in this condition by narrative literature review according to the search strategy and methodologies indicated here below.

\section{Search strategy and methodology}

In this narrative review, six online bibliographic databases were searched from inception to May 30, 2020: MEDLINE (from 1946), Embase (from 1946), PubMed (from 1966), Cochrane CENTRAL (from 1996), Web of Sciences (1997), and Scopus (from 2004).

We used an empirical and topical approach to derive an objective primary search strategy for identifying clinical, laboratory, and therapeutic studies of digital interventions that included West syndrome, infantile spasms, and infantile spasms syndrome.

In the first step, we identified a test set of critical papers meeting our broad inclusion criteria by introducing in the search bar the major MeSH term "West syndrome" $(18,584$ results) OR "infantile spasms" (4569 results) OR "infantile spasm syndrome" (2273 results); the search strategy was developed in MEDLINE using article identification numbers, and the search strategy was iteratively improved to maximize the sensitivity and specificity for identifying relevant articles. This search strategy achieved $100 \%$ sensitivity against these initial test sets. Following this step, key search terms derived from the medical subject heading terms used in the test papers were established, which included 12 primary sets of terms pertaining to "West syndrome" OR "infantile spasms syndrome" studies (both terms indicated in all paragraphs here below in parentheses and separated by semicolons) and digital interventions: these relevant terms included (AND) "clinical spasms" (1866; 1061 results), "epileptic spasms" (4601; 2263 results), "electroencephalography" (1807; 868 results), "electroencephalographic" (323; 169 results), "EEG" (1205; 1021 results), "Video-EEG" (59; 49 results), "mental retardation" (1579; 656 results), "developmental delay" (485; 285 results), "developmental regression" (101; 44 results), "intellectual disability" (1541; 538 results), "cognitive" (788; 205 results), and "disability" (1431; 516 results).

We conducted a second search and introduced in the search bar the MeSH term "West syndrome" OR "infantile spasm syndrome" AND "inborn errors of metabolism" (320; 83 results), "brain malformation(s)" (1047; 461 results), "chromosome/chromosomal" (758; 214 results), "neurocutaneous syndromes/disorders" (325-330; 96-99 results) OR "phacomatosis/phacomatoses" (327; 96 results), "immune/ immunology", "immunological" (42-46 results), "infective/ infectious" (796; 21 results).

A third search included in the search bar the MeSH term "West syndrome" OR "infantile spasm syndrome" AND "gene" OR "genetics" (767-1800; 432-2263 results), "protein(s)" (4654; 738 results), and "pathway" (4653; 729 results).

An additional, and fourth search included the MeSH terms "West syndrome" OR "infantile spasm syndrome" AND "therapy/treatment" (8169-9487; 1022-1180 results) OR “outcome" (3414; 551 results) OR "prognosis" (3414; 851 results).

A variety of terms related to each of these terms were entered into each database. References of relevant sources, which were manually examined to identify any additional relevant studies, were included in the reference list. After the removal of duplicate records, two reviewers (PP and MR), in their mid/advanced-career research, trained in this method, independently screened the titles and abstracts for relevance, and then extracted and selected relevant full-text records and pivotal papers known to either reviewer. Discrepancies were resolved through discussion at each stage, and a consensus was achieved with acceptable inter-rater reliability.

Notably, when we coupled in our search the MeSH term "West syndrome" vs. "infantile spasm syndrome", the results were more significant, in all searches carried out, in the former matching, meaning that the classical term West syndrome is still more incardinated and most widely used in the literature.

A separate search was conducted in the OMIM ${ }^{\mathrm{TM}}$ (Online Mendelian Inheritance in Man, 2020) database (available at https://www.omim.org) by entering the term "West syndrome" OR "infantile spasm" OR "infantile spasm 
syndrome": the main results of this search are listed in Table 1 and discussed throughout the review.

Table 1 list of the most frequent genes associated to ISS

\begin{tabular}{|c|c|}
\hline Gene & Cytogenetic location \\
\hline$A R X$ & Xp21.3 \\
\hline CDKL5 & $\mathrm{Xp} 22.13$ \\
\hline PAFAH1B1/LIS1 & $17 \mathrm{p} 13.3$ \\
\hline$D C X$ & $\mathrm{Xq} 23$ \\
\hline$T U B A 1 A$ & $12 \mathrm{q} 13.12$ \\
\hline$S T X B P 1$ & $9 q 34.11$ \\
\hline$K C N Q 2$ & $20 \mathrm{q} 13.33$ \\
\hline SPTAN & $9 \mathrm{q} 34.11$ \\
\hline MAGI2 & $7 \mathrm{q} 21.11$ \\
\hline GRIN2A & $16 \mathrm{p} 13.2$ \\
\hline FOXG1 & $14 q 12$ \\
\hline$N S D 1$ & $5 q 35.3$ \\
\hline NEDD4 & $15 \mathrm{q} 21.3$ \\
\hline$C A L N 1$ & 7q11.22 \\
\hline WDR45 & $\mathrm{Xp} 11.23$ \\
\hline SLC1A4 & $2 \mathrm{p} 14$ \\
\hline$R A R S 2$ & $6 \mathrm{q} 15$ \\
\hline$U B A 5$ & $3 \mathrm{q} 22.1$ \\
\hline IARS2 & $1 \mathrm{q} 41$ \\
\hline PHACTR1 & $6 \mathrm{p} 24.1$ \\
\hline$A T P 2 A 2$ & $12 q 24.11$ \\
\hline CD99L2 & $\mathrm{Xq} 28$ \\
\hline CLCN6 & 1p36.22 \\
\hline CYFIP1 & $15 q 11.2$ \\
\hline CYFIP2 & $5 \mathrm{q} 33.3$ \\
\hline GNB1 & $1 \mathrm{p} 36.33$ \\
\hline GPT2 & $16 q 11.2$ \\
\hline HUWE1 & $\mathrm{Xp} 11.22$ \\
\hline$K M T 2 D$ & $12 q 13.12$ \\
\hline МYO18А & 17q11.2 \\
\hline NOS3 & 7q36.1 \\
\hline$R Y R 1$ & 19q13.2 \\
\hline$R Y R 2$ & $1 q 43$ \\
\hline RYR3 & $15 \mathrm{q} 13.3-\mathrm{q} 14$ \\
\hline TAF1 & $\mathrm{Xq} 13.1$ \\
\hline TECTA & $11 \mathrm{q} 23.3$ \\
\hline PURA & $5 \mathrm{q} 31.3$ \\
\hline
\end{tabular}

$A R X$, aristaless related homeobox; ATP2A2, ATPase sarcoplasmic/ endoplasmic reticulum $\mathrm{Ca} 2+$ transporting 2; CALN1, calneuron 1; CD99L2, CD99molecule like 2; CDKL5, cyclin dependent kinase like 5; CLCN6, chloride voltage-gated channel 6; CYFIP1, cytoplasmic FMR1 interacting protein 1; CYFIP2, cytoplasmic FMR1 interacting protein; $D C X$, doublecortin; FOXG1: forkhead box G1; GNB1, G protein subunit beta 1; GPT2, glutamic-pyruvic transaminase 2; GRIN2A, glutamate ionotropic receptor NMDA type subunit 2; HUWE1, HECT,UBA,WWE domain containing 1; IARS2, isoleucyl-tRNAsynthetase 2, mitochondrial; $K C N Q 2$, potassium voltage-gated channel subfamily $\mathrm{Q}$ member 2; KMT2D, lysine methyltransferase 2D; MAGI2, membrane associated guanylatekynase; MYO18A, myosin XVIIIA; NEDD4, neural precursor cell espressed, developmentally down regulated 4-2, E3 ubiquitin protein ligase; NOS3, nitric oxide synthase 3; NSD1, nuclear receptor binding SET domain; PAFAHIB1, platelet activating factor acetylhydrolase; PHACTR1, phosphatase and actin regulator 1; $P U R A$, purine rich element binding protein A; RARS2, arginyl-tRNAsynthetase 2, mitochondrial; RYR1, ryanodine receptor $1 ; R Y R 2$, ryanodine receptor $2 ; R Y R 3$, ryanodine receptor $3 ; S L C 1 A 4$, solute carrier family 1 member 4; SPTAN: spectrin alpha, non-erythrocytic
In addition to all of that, we also introduced and commented on the first article by William J. West, 1841 [1].

\section{Etiologic factors}

\section{ISs-one syndrome (one phenotype) for many different etiologies}

The overall spectrum of the so-called ISs, as it occurs for other neurological disorders, including epileptic seizures and cognitive and behavioral developmental disabilities, is caused by different pathogenic events, some of which are still unknown while others are well-recognized structural, infectious, metabolic and immunologic defects and genetic abnormalities [6]. All these factors may act, mostly, as single causal events or in complex associations. Often, an obvious etiologic distinction is not strictly feasible, since different events may concur in causing the ISs. In about $35 \%$ of cases, the etiologic event is (still) unknown: the outcome, in these cases, is usually more favorable as compared with the group with recognizable etiologies. Yuskaitis et al. [13], reported in 133 infants with ISs of unknown origin, normal development in $15 \%$ vs. clinically well-documented developmental delay in the remaining $85 \%$.

The causes of ISs may have their origin in the prenatal, perinatal, and post-natal period. The hypoxic-ischemic encephalopathy is reported as one of the most common causes of ISs. In the study carried out by the "United Kingdom Infantile Spasms Study" (UKISS) [14], in 127 out of 207 patients affected by ISs with proven etiological diagnosis, hypoxic-ischemic encephalopathy was reported in $10 \%$, followed by chromosomal abnormalities, complex malformation syndromes and perinatal stroke (8\%), tuberous sclerosis (7\%), and periventricular leukomalacia or hemorrhage (respectively, in 5\%). Hypoxic-ischemic encephalopathy, prenatal cerebral infections, and stroke may act causing permanent cerebral damage manifesting subsequently with ISs. It must be noted that many of the etiologic events in the UKISS study [14] are similar from a strict pathogenic viewpoint: e.g., the molecular/cellular events leading to the typical brain defects in tuberous sclerosis (which is regarded as a malformation of cortical development) are similar to the events occurring in some complex malformation syndromes or in chromosomal abnormalities with brain structural defects. That may occur as the cascade of involved genes/proteins belongs to common intracellular signaling pathways. Most importantly, many recent studies highlight that vascular events (of all types: i.e., hypoxic, ischemic, stroke), infections, metabolic and immunologic defects, may act on a genetic predisposing background $[15,16]$. More recently, the results of a study carried by the "National Infantile Spasms Consortium" in North America on $161(64.4 \%)$ out of 250 ISs patients in whom the etiologic cause was achieved, revealed that genetic factors 
were recognized in $14.4 \%$, genetic-structural in $10.0 \%$, structural-congenital in $10.8 \%$, structural-acquired in $22.4 \%$, metabolic in $4.8 \%$, and infectious in $2 \%$ [17]. In this respect, according to the widest epidemiologic studies, geneticmolecular involvement has been increasingly recorded in patients with ISs when using modern genetic technologies (i.e., array-CGH, NGS, WES, and WGS), allowing the identification of an increasing number of genes or copy number variants (CNVs) involved in the direct expression of the ISs $[15,16]$. The molecular/cellular anomaly may act directly in generating by itself the neuronal/brain structural phenotype underlying the ISs or indirectly by causing a complex syndromic phenotype (i.e., a recognizable malformation syndrome or an inborn error of metabolism) or by predisposing (at the cellular level) to a vascular or infectious event [16]. Genetic causes may be involved in yielding the ISs through several mechanisms: chromosomal or large/single gene abnormalities, or CNV, or a mixture of all of these factors.

\section{The role of genetics as an etiologic factor}

As reported by Scheffer et al. [6], the majority of genes involved in ISs [see Table 1] show a phenotypic heterogeneity, as it occurs with other neurological disorders.

A genetic predisposition to cause ISs was advanced by Dulac et al. [18] and by Hemminki et al. [19], on the basis of the observation that the chance of having ISs was increased in families in which other members were affected by epileptic seizures. A genetic predisposition in cases of ISs was also confirmed by reports of IS in twins. In this latter respect, Pavone et al. [20] first described the occurrence of IS in a set of monozygotic twins who had their onset of spasms within a short interval of time (a few hours) one from the other. Similar findings were recorded by Coppola et al. [21] in three independent sets of monozygotic twins: in each set of twins, the epileptic spasms appeared on the same day, within hours one twin from the other. This phenomenon is difficult to explain: we could only hypothesize that a time-related, preprogrammed molecular/cellular event may act triggering, in a given individual, the onset and the overall occurrence of spasms, somewhat similar to the programmed phenomena of apoptosis and cellular death occurring during life $[15,20]$. A different, likely complementary, explanation could be that environmental triggers affect (ISs) genetically predisposed monozygotic twins at the same time [15].

Direct involvement of genes in the etiology of ISs was related to the detection of mutations of the Aristaless-related homeobox $(A R X 1)$ gene and the Cyclin-dependent Kinaselike 5 gene (CDKL5), both located in the human chromosome $\mathrm{Xp} 22$ region, in patients affected by complex malformation phenotypes with IS/ES $[15,16]$. These two genes are widely expressed in fetal brains and their role in brain developmental has been firmly demonstrated [4, 15, 16, 22-27].
As reviewed by Paciorkowski et al. [16], mutations in other-than-X-linked genes, including $P A F A H 1 B 1 / L I S 1$, $D C X$, and TUBA1A are also frequently associated with ISs [15]. These genes are expressed in GABAergic interneurons and their mutations have been regarded as a direct cause of ISs, secondary to neuronal cell disruption during embryogenesis [8, 16, 24]. Other ISs-causing genes include STXBP1 [28, 29], KCNQ2 [30], GRIN2B, and GRIN2A [31, 32], and MAGI2 [33]. Further and more recent causative mutations of genes involved in the pathogenesis of ISs include the SPTAN, FOXG1, and NSD1 genes [11], thus confirming the wide variety of involved genes causing ISs. A study of Boutry-Kryza et al. [32], on 73 patients with different types of ISs, by means of array-CGH testing and genomic sequencing revealed anomalies in CNVs in multiple genes in up to $15 \%$ of patients, including three patients who harbored specific point mutations in CDKL5 and STXBP1 genes; they also recorded [32] ISs patients yielding microdeletions in the $2 \mathrm{q} 24.3,5 \mathrm{q} 14.3$, and 9 p34 regions, respectively; and microduplications in the 2q24.3 and Xp28.11.93 regions. According to the same study [32], the 16p12.1 deletions recorded in their ISs series, which included intronic deletions of the NEDD4 gene and intronic deletions of CALN1 gene, could be regarded as potential risk factors for ISs.

Recent studies have expanded the spectrum of ISsassociated genes, by including mutations in WDR45 [34, 35], KCNQ2 R198Q [36], SLC1A4 (variant) [37], RARS2 [38], UBA5 [39], IARS2 [40], hCDKL5 [41], and PHACTR1 [42] genes. A study on a cohort of 56 Chinese families with ISs screened by means of WES, revealed 17 novel ISscandidate genes: ATP2A2, CD99L2, CLCN6, CYFIP1, CYFIP2, GNB1, GPT2, HUWE 1, KMT2D, MYO18A, NOS3, RYR1, RYR2, RYR3, TAF1,TECTA and UBA [43].

Most recently, ISs children harboring 5q31.2-q31.3 microdeletions (a region embedding the PURA (purine-rich element binding protein A) gene), were reported by Shimojima et al. [44]. De novo mutations in the PURA gene are responsible for a neurodevelopmental disorder (the socalled PURA syndrome) characterized by severe intellectual disability, epilepsy, feeding difficulties, and neonatal hypotonia associated to respiratory and gastrointestinal problems, eye anomalies, endocrine defects, exaggerated startle responses, hyper somnolence, and hypothermia [45]. These latter findings further demonstrate how wide and complex is the "evolving" spectrum of neurodevelopmental disorders including (typical and atypical) IS in their phenotypes $[15,16]$.

\section{Additional causal factors}

\section{Structural brain disorders}

Structural brain abnormalities are well-known causes of IS and ISs: lissencephaly, focal cortical dysplasia, polymicrogyria, 
hydranencephaly [46], and hemimegalencephaly are some examples of ISs-underlying developmental brain anomalies. Specifically, the PAFAH1B1/LISI and DCX genes, which are related to classical lissencephaly, appear to be associated to ISs in about $80 \%$ of affected children. A de novo heterozygous mutation of KIF $2 A$ gene has been reported in a child with lissencephaly, developmental delay, and IS [47]. Recently, a child with IS and periventricular nodular heterotopia was found to harbor an unbalanced chromosomal translocation 3p26.210p15.1 and a 6q22.31 duplication [48]. A child with a novel homozygous nonsense mutation in the B3GALNT2 gene was reported with clinical features compatible with a diagnosis of Walker-Warburg syndrome, ISs, and sensorineural hearing loss [49].

\section{Complex malformation syndromes}

The Down, Pallister-Killian, and Williams-Beuren syndromes have been often associated to ISs.

In a study of 183 Down's syndrome patients admitted to our institution in the 1990s, 15 complained of epileptic seizures and among these 4 suffered from ISs [50]. According to Tapp et al. [51], the prevalence of epileptic seizures in patients affected by Down's syndrome ranges from 1 to $13 \%$ : among these 6-32\% present with ISs.

Mosaicism for tetrasomy of chromosome $12 p$ is the main cause of Pallister-Killian syndrome: affected patients show skin pigmentation, bitemporal alopecia, rugged-looking face, epileptic seizures, and intellectual disability. Notably, these patients present late-onset epileptic spams [52].

Williams-Beuren Syndrome (WBS) is linked to a chromosomal microdeletion manifesting with characteristic facial features and heart problems associated with intellectual disability and happy and affable behavior. Marshall et al. [33] reported on a WBS patient with ISs harboring a large deletion on chromosome 7q11.23-q21.11 embedding the MAGI2 gene.

Anecdotal cases of ISs have been reported within the context of Schinzel-Giedon, Smith-Lemli-Opitz, Smith-Magenis, and Sotos syndromes [11].

Epileptic spasms have been also recorded in a male infant with $P P P 1 C B$-associated Noonan-like syndrome [53].

ISs-associated features are the presenting manifestations of two well-characterized syndromes: the PEHO and Aicardi syndromes. The PEHO syndrome is a rare and progressive encephalopathy presenting with edema, hypsarrhythmia, and optic atrophy with remarkable cerebellar atrophy due to granule neuron loss. Recently a mutation in the ZNHIT3 gene has been identified as its primary cause [54]. Aicardi syndrome is a neurodevelopmental syndrome affecting the female gender: corpus callosum agenesis, retinal lacunes, severe intellectual disability, and ISs with an EEG showing asymmetric hypsarrhythmia are the main abnormalities; brain tumors, especially affecting the choroid plexus have been also reported [55].

\section{Inborn errors of metabolism}

Phenylketonuria (PKU) is an inborn metabolic disorder caused by a mutation of the gene encoding for the enzyme phenylalanine hydroxylase (PAH), which converts the amino acid phenylalanine into tyrosine and other components. In the pre-screening era, the PKU incidence was as high as 1 in 5000 newborns and was characterized by skin hypopigmentation, severe developmental delay, and seizures including ISs. In untreated patients, severe brain demyelination and abnormalities in gray matter are responsible for the severe cerebral involvement. A rare but more severe subtype of PKU is a disorder related to tetrahydrobiopterin (BH4) deficit, a coenzyme of PAH. In untreated patients, developmental delay and epileptic seizures of the ISs type are almost constantly reported [56]. Early-onset inborn errors of metabolism may present with ISs as their first manifestation. Alrifai et al. [57] in a group of 80 children presenting with ISs, recorded a diagnosis of neurometabolic disorders in 10 (12.5\%): among these, two showed a Leigh-like disorder, the others were affected by ethylmalonicaciduria, non-ketotichyperglycinemia (caused by the GCSH gene), hyperinsulinemic hypoglycemia (HHF17), short-chain acyl-coenzyme A, dehydrogenase deficiency (caused by the $A C A D S$ gene), molybdenum cofactor deficiency (subtypes MOCS12; caused by the GPHN gene), primary carnitine deficiency (caused by the SLC22A5 gene), and neonatal hypoglycemia secondary to hypopituitarism (subtypes CPHD15). ISs may be also a clinical feature in children with glycine encephalopathy (caused by the GLDC and GCST genes); DEND (developmental delay, epilepsy, neonatal diabetes caused by the KCNJ 11 gene); methylmalonicaciduria (caused by the $M U T$ gene), maple syrup urine disease (caused by the BCKDHA, BCKDHB, DBT, and $D L D$ genes) and propionic acidemia (caused by the $P C C A$ and $P C C B$ genes).

ISs have been also reported in children with neurodegenerative disorders including globoid cell leukodystrophyKrabbe disease (caused by the GALC gene) and Menkes disease (caused by the ATP7A gene) [58-60]. Rare disorders associated with ISs also include cerebrotendineous xantomatosis (caused by the CYP27Al gene) [61]; glucose transport 1 deficiency (caused by mutations in exon 9 of the SLC2A1 gene) [62]; disorders of glycosylation [63] (caused by the $A L G 1,6,11$ genes: subtypes $C D G$ and $C D G 1 x$ ). Pyridoxine-dependent epilepsy (PDE) may present with various types of severe seizures, partial and generalized seizures, atonic and myoclonic seizures, convulsive status epilepticus, and ISs $[64,65]$. Mutation in ALDH7al gene encoding the alfa-amino-adipic-semialdehyde (alfa AASA) dehydrogenase (antiquitin) is a well-recognized cause of epileptic seizures 
including ISs $[16,65]$. As reported by van Karnebeek et al. [64], PDE may manifest with atypical features with late-onset and different response to the pyridoxine and metabolic disturbances like hypoglicemic episodes, lactic acidosis, and electrolyte anomalies. Neurotransmitter and neuroimaging abnormalities may precede the onset of ISs [65]. We have followed an infant with ISs clinically and EEG confirmed in whom treatment with large daily supplements of pyridoxine resulted in disappearance of the symptoms. (Fig. 3A, B).

\section{Neurocutaneous disorders (phacomatoses)}

ISs may be one of the (earliest) manifestations in some neurocutaneous disorders or phacomatoses. Within this context, affected children typically show non-casual associations of congenital skin (and eye) anomalies and central (and peripheral) nervous system structural abnormalities (and/or tumors), and neurological manifestations, often associated to systemic involvement (e.g., the heart and vessels, lung, kidney, and bone) [66-68].

\section{Tuberous sclerosis complex (TSC)}

TSC is the most common example of a neurocutaneous disorder typically associated to ISs $[69,70]$. TSC-affected children often (up to $>90 \%$ of cases) present with different epileptic seizure types [70]. Mutations in either the TSC1 or TSC2 genes, through the hamartin/tuberin complex and mTOR pathway, cause neuronal/interneuronal disruption, which in turn leads to a malformation of brain cortical migration and layering, which is reflected by the development of cortical tubers, white matter anomalies, subependymal nodules (and related subependymal giant cell astrocytoma), and brain cysts [71]. These brain structural abnormalities form the basis of susceptibility to manifest epileptic seizures (and of the overall neurodevelopmental, behavioral, and cognitive defects) [72] In a study on a population of 81 TSC children with a median age of 10 years, epileptic seizures occurred in $91 \%$, including $32 \%$ with a history of ISs [73]. Several studies documented an important decrease (in frequency and severity) vs. cessation of seizures in TSC patients with drug-resistant epilepsy (including individuals with a past history of ISs) treated with focal cortical tuber resection $[74,75]$. New treatments with single and/or combined m-TOR inhibitors have been proposed in patients with TSC and (drug-resistant) epilepsy, including ISs, but criticism was raised by the remarkable side effects related to their use and by the relatively poor efficacy over time [76-78].

\section{Neurofibromatosis type 1 (NF1)}

Patients with NF1 show a genetic predisposition to the development of benign (and, less frequently, malignant) central and/or peripheral nervous system and systemic tumors, which are related to the effect of loss of neurofibromin, the NF1 gene protein product $[66,68,79,80]$. In a cohort of $630 \mathrm{NF} 1$ patients, 37 (5.87\%) suffered from epileptic seizures: among these, the most common seizures types were partial and primary generalized, with only two children presenting with ISs [81]. In a large multicenter hospital-based study and systematic review of the literature, the NF1 children presenting with IS represented only $1.5 \%$ of the NF1 population, most having a more favorable outcome [82]. Seizures, epilepsy, and infantile spasms, within the context of NF1, have been related to disruption in the ras/NF1-related MEK/MAPK/ERK signaling pathway $[68,82]$.

\section{Sturge-Weber syndrome}

Capillary vascular malformations of the embryonic facial vasculature, the leptomeninges (including underlying neuronal disarrays) and the choroidal eye layer are the main features of SWS $[66,68,83]$. This complex vascular developmental disruption syndrome is caused by somatic mutations in the GNAQ gene, a nuclear structural gene responsible for vessels and neuronal development [84]. Epileptic seizures (as well as cognitive and behavioral abnormalities) are the most frequent clinical manifestations of the disease and are reported to occur in up to $77 \%$ of patients with unilateral, and $92 \%$ with bilateral brain involvement $[68,85,86]$. The epileptic seizures are mainly of the partial but also tonic-clonic generalized types [86]: ISs have been sporadically recorded [86, 87].

\section{Pigmentary mosaicism of (the hypomelanosis of) Ito type}

Seizures and epilepsy, occasionally including ISs, can be recorded in children (and adults) with skin pigmentary (usually of the hypopigmented type) whorls and streaks following the lines of Blaschko (i.e., a system of lines in the skin reflecting the arrangement and migration patterns of pigmentary cells in the human embryo and later in postnatal life). Affected individuals can present also associated extra-cutaneous abnormalities mostly affecting the eye, musculoskeletal, and nervous systems: this latter complex malformation phenotype is currently known as hypomelanosis of Ito, a condition which reflects somatic mosaicism for some, yet unknown, pigmentary genes) [88, 89]. Epilepsy, and the occurrences of ISs, within the context of hypomelanosis of Ito, is likely due to the minor (mosaic) migration disordering (manifesting as white matter disarray) typically associated to the (more severe) complex neurological phenotype [89, 90]. 


\section{Role of immunity}

Recent studies have hypothesized the possible role of immunologic events as triggering factors of ISs. This is related to the observation that some genes, involved in the pathogenesis of ISs, play also crucial roles in a variety of inflammatory cascades and signaling pathways [91]. Lemke et al. [31] reported mutations in the GRIN2B gene (which encodes the NR2B subunity of the N-methyl-aspartate (NMDA) receptor), in two children with ISs: NMDA receptors are involved in a number of neurological disorders [31]. Notably, elevated titers of antibodies against the voltage-gated potassium-channel complex proteins $(\mathrm{VGKC}$ ) (i.e., $201 \mathrm{pmol} / \mathrm{L}$; normal values $=<100$ ) were reported in an infant aged 4 months with ISs [92].

\section{Pathogenesis}

The overall pathogenesis of ISs may present with many obscure aspects: as previously summarized, a number of factors can cause ISs and thus it may prove difficult to explain each single event causing ISs [15, 16, 93]. There are well-documented examples of ISs originating from whole cortical involvement, as it occurs with lissencephaly, or from focal cortical disarrangements, as recorded in children with polymicrogyria or in individuals with cortical tubers and white matter disarray secondary to TSC, or from subcortical impairment as it occurs in children with hydranencephaly. The most likely scenario could be that of a disruption of the normal brain neuronal/interneuronal network(s) (either at the molecular, receptor, or cellular level) $[15,16]$ leading in turn to abnormal interactions between cortical and subcortical structures [93]. Another issue that needs clarification is the (apparent) discordance between the general diffuse (EEG) pattern of hypsarrhythmia (coupled to the generalized clinical pattern of spasms) and the focal cortical lesions recorded in many cases of ISs. An hypothesis is that the focal cortical lesions may spread down to the basal ganglia thus providing the basis for making it manifesting both the clinical (generalized) appearance of spasms and the hypsarrhythmia pattern [93-95]. A further issue to clarify is the cognitive/intellectual disability and the autism spectrum disorder (ASD) often associated to (but also preceding the onset of) ISs. Deletions of $S C N 2 A$ and $S C N 3 A$ genes were found in a young boy with autistic spectrum disorder and ISs [96]. These [96], and other findings (reviewed $[15,16]$ ) seem to support the hypothesis of a genetic (predisposing) background leading at the same time to the appearance of IS and the cooccurrence of a mixed cognitive/behavioral defect, including the intellectual disability and the autism spectrum phenotype.
Clinical features, seizure types, and EEG features

\section{ISs vs. West syndrome}

WS is regarded as a subtype of ISs and is the most frequently reported subtype presenting in about $90 \%$ of cases of ISs. WS encompasses the triad of infantile spasms, hypsarrhythmia, and developmental arrest or regression. The classical presentation of WS consists in short episodes of abrupt flexion of the trunk and neck and adduction of the arms, with onset in infancy or early childhood. The tonic spasms are bilaterally symmetric, each lasting few seconds and occurring at wakening and in clusters. EEG recording typically shows a hypsarrhythmic pattern consisting in chaotic mixture of very high amplitude slow waves with discharges of waves and spikes varying in amplitude, morphology, duration, and site. Psychomotor delay or developmental regression is associated features $[11,12]$.

ES (i.e., the newer term for IS) are regarded as a component of WS, and are clinically defined by abrupt contractions followed by a tonic contraction lasting a few seconds with involvement mainly of the muscles of the neck, trunk, and limbs with abduction or adduction of the arms. The spasms may appear in flexion, extension or in mixed patterns with episodes of cry or scream, which may precede or follow the spasm itself. The spasms appear mostly in rapid sequence and occur prevalently just before sleep or on awaking. In the most severe ictal phenotypes, the spasms may be noticed also during sleep. During the crises, the eyes may be fixed or deviated and there can be cardiac and respiratory involvement. Affected children after the crises may be irritable or may have drowsiness [17, 97, 98]. The spasms may occur in association with episodes of facial grimacing, transient focal movements, and blinking [11, 99]. In general, the onset of spasms occurs between 4 and 9 months with a peak around the 6th month of life: in about $80-90 \%$ of cases, the spasms manifest within the first year of life. In the initial phase of the disorder these phenomena may pass unnoticed and overlooked by parents [15]. As reported by Hussain et al. [100] in a study carried out in 100 patients with ISs the treatment was started only after more than a week from the onset of the first clinical manifestations with a median time of delay of treatment of 24.5 days. Wang et al. [101] developed an algorithm using medical claims data at the aim to properly and early identify the ES.

Aside the above reported, classical ictal phenomena, atypical patterns of clinical (and EEG) manifestations of ISs are well known. Atypical patterns may be related to the age of the child at onset of spasms and to the etiologic factors underlying the disorder. 


\section{ISs-atypical presentations vs. association of spasms with other seizure types}

IS may present with hypsarrhythmia but without clearly definable clinical signs: these spasms are indicated as "Subtle Spasms". Slow abnormal limbs movements, facial grimacing, isolated fixed eyes, slow trunk rotation may be the only clinical expressions of ISs and can be associated to other seizure types.

Xue et al. [102] recorded, in 12 ISs children, three different patterns of atonic spasms combined or uncombined with typical IS: spasms-atonic, pure atonic, and atonic-spasms seizures.

In a study on 48 patients presenting with IS in clusters without hypsarrhythmia Caraballo et al. [103] was able to recognize two subgroups: (1) in 30/48 patients he recorded a well-defined electroclinical syndrome with IS manifesting mainly in infancy; (2) in 18/48 there were variable patterns of electroclinical syndromes manifesting as epileptic encephalopathies other-than-ISs, as the main clinical manifestation; among these 48 patients, nine had electroclinical features of Lennox-Gastaut syndrome, four myoclonic and atonic seizures, two were affected by Dravet syndrome of whom one presented with epilepsy of infancy with migrating focal seizures. Other children showed non-convulsive status epilepticus with atypical absences and also clinical features of subacute sclerosing panencephalitis.

"Single ES" are defined as no other spasms occurring for $1 \mathrm{~min}$ before and after each other. A group of 16 children with this clinical phenotype was clinically evaluated by Caraballo et al. [104]: 9/16 patients showed a hypsarrhythmic EEG pattern, which was not recorded in the remaining 7/16. Overall, in these patients, other types of seizures were also recorded, both before and during their epileptic spasms. An infant with a triad of a clusters of IS, vertical binocular nystagmus, and focal tonic seizures manifested during a single ictal event was reported by Tarodo et al. [105].

In general, the age of presentation of the spasms well correlates with the clinical and electroencephalographic patterns but there are some exceptions. Recently, some of us reported a child with Miller-Dieker syndrome and IS [106]: initially, the seizures were of the subtle spasms type with an EEG pattern of modified hypsarrhythmia (Fig. 1). A month later, the EEG pattern remained unchanged (focal discharges), whereas the epileptic spasms assumed the typical aspect of IS (Fig. 2). An analysis of infants with spasms in comparison to infants with other seizures types was conducted by Berg et al. [107]: according to this study, the age at onset of spasms was similar in infants initially presenting with typical spasms (6.1 months) vs. infants with spasms developing at (slightly) older ages (6.9 months); conversely, the age at onset of the other-thanIS seizure types was lower ( 4.7 months, $p<0.0001$ ), demonstrating that the classical spasms develop around a given and well-defined age. Notably, no correlation between gestational age and age at onset of spasms was recorded [107].

\section{Atypical EEG patterns}

Besides the classical hypsarrhythmic pattern with background chaotic activities and disorganization with multifocal sharp waves and spikes (interictal brain activity) and decrement background activity (ictal event), other EEG patterns may be observed during the course of the IS syndrome. These different patterns are defined as "atypical" or "modified hypsarrhythmia" and consist of asymmetric features, focal discharges, and semi-periodic burst-suppression [11]. Focal EEG activities have been recorded through scalp EEGs as ictal gamma and beta activity during IS by Nairai et al. [108].We personally recorded focal activity, in a child with MillerDieker syndrome, mainly localized in the occipital areas [106].

\section{Differential diagnosis and diagnostic approaches to children with presumed ISs}

Two distinct clinical disorders may mimic the symptoms of ISs: (1) benign spasms of infancy usually manifesting in the first year of life; and (2) myoclonic epilepsy of infancy. Diagnostic assessment in children with ISs involves several aspects. Taking an accurate family history and performing a detailed general physical examination, particularly focused to get a full neurological assessment (including fundoscopy) but also aimed to exclude systemic anomalies involving the skin, face, heart, limbs, internal, and genital organs form the basis of a first diagnostic approach to a child with IS. A complete video-EEG recording is the next step and then, if the diagnosis of ISs is confirmed, further steps include ultrasound examination of the heart and internal organs and a magnetic resonance (MR) study of the brain (and the spine, when dictated by the clinical findings). In a retrospective review of 71 ISs cases, brain abnormalities at MR were found in 52/71 [109]: these 52 positive-MR children were divided into two subgroups, supposed (1) developmental and (2) acquired, both presenting with cortical gray and/or white matter abnormalities. ArrayCGH analysis represent the first step for searching chromosomal abnormalities and/or deletions/duplications; further genetic testing should include oriented NGS analysis, or NGS analysis comprehensive for whole epilepsy gene panels; when available, WES and WGS should complete the genomic analyses, especially in cases negative to array-CGH and NGS. Metabolic assessment are mandatory when the disorder shows a rapid progression [17, 93-95]. 
Fig. 1 A six-month-old infant presenting slow movements of trunk rotation ("subtle spasms")
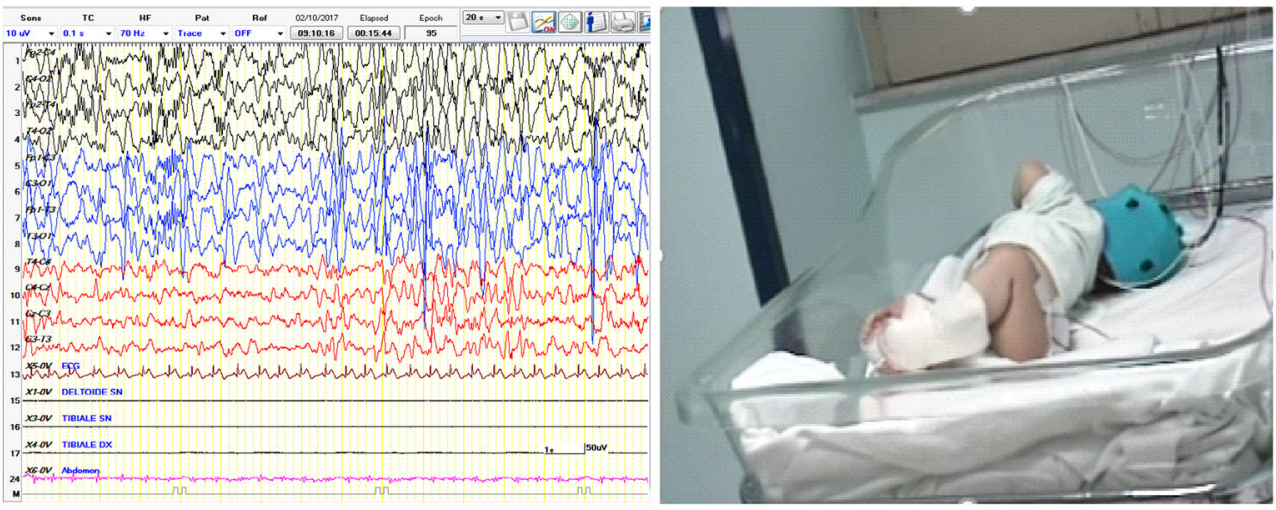

\section{Treatment}

An early diagnosis and a shorter lag time to start treatment still represent the golden standards to get an effective response. Once the diagnosis of ISs is made, a therapeutic attempt should be started with a bolus of pyridoxine at the dose of $150 \mathrm{mg}$ in 5-10 min, to exclude pyridoxine-dependent epilepsy: in this latter case, a rapid improvement of spasms and EEG abnormalities will be recorded within a few hours (Fig. 3).

The gold standard therapy for ISs consists in the administration of adrenocorticotrophic hormone (ACTH), vigabatrin (VGB), and corticosteroids [110, 111].

ACTH is used with a large variation of dosage, depending on the experience of each Institution. In a study on 200 ISs children, treatment with ACTH at the dose of 2-3 IU/kg/day was more effective as compared to treatment at the dose of $1.1-1.9 \mathrm{IU} / \mathrm{kg} /$ day (or $1 \mathrm{IU} / \mathrm{kg} /$ day or even $3.1-4 \mathrm{IU} / \mathrm{kg} /$ day) $(p<0.01)$ [112]. Most studies however, and the majority of personal experiences gained worldwide, suggest that low doses are as effective as high doses [113]. ACTH treatment should be stopped after 3-4 weeks after initiation of the therapy; however, as suggested by D'Alonzo et al. [114], treatment with prednisolone at the dose of 40-60 mg/day prolonged for 14 days has been considered effective and well tolerated. Potential side effects are immunosuppression and infections, hypertension, metabolic reactions, and renal failure
[93, 110]. Prednisolone is supposed to act by regulating and improving the ISs-related immune dysregulation [110]. Wanigasinghe et al. [115] in a study conducted on a cohort of ISs children after 3 months of treatment recorded a better control of spasms in the ISs children initially treated with prednisolone as compared with children treated with i.m. ACTH. In other studies, however, no significant difference was found between children treated with ACTH vs prednisolone [116]. Pyridoxine, as additional therapy to ACTH or prednisolone, has been used with contradictory results. In a pilot study, carried out in 62 ISs children with comparable baseline clinical and EEG features divided in two groups: (1) oral prednisolone alone vs (2) combination of prednisolone with pyridoxine, no beneficial effects were recorded in group 2 [117].

Ketogenetic diet has been proposed as an alternative and effective treatment in ISs. The diet consists in an intake composed of high fats, adequate proteins, and low carbohydrates. Kossoff [118] reported effectiveness of this diet in ISs patients both in reducing/stopping the spasms and in normalizing the EEG. Good outcomes have been also achieved with a modified ketogenic diet using MCT oil-the ATKINS diet (MA), which consists of a combination of very low carbohydrate elements (medium chain triglyceride, at a dose of $10 \mathrm{~g} /$ day) and high fat food intake. This treatment is reported to
Fig. 2 The same infant of Fig. 1 1 month later showing focal discharges and classical epileptic spasms

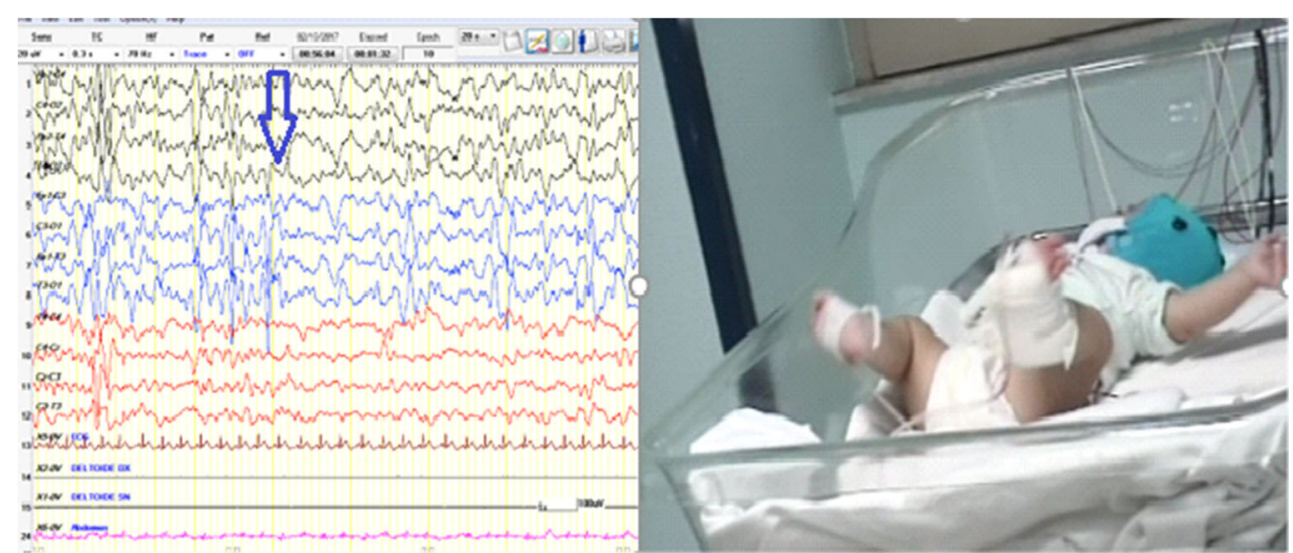


Fig. 3 (a) Frame of video-EEG of a 6-month-old infant with pyridoxine-dependence before treatment with vitamin B6; (b) frame of video-EEG a day after treatment with pyridoxine
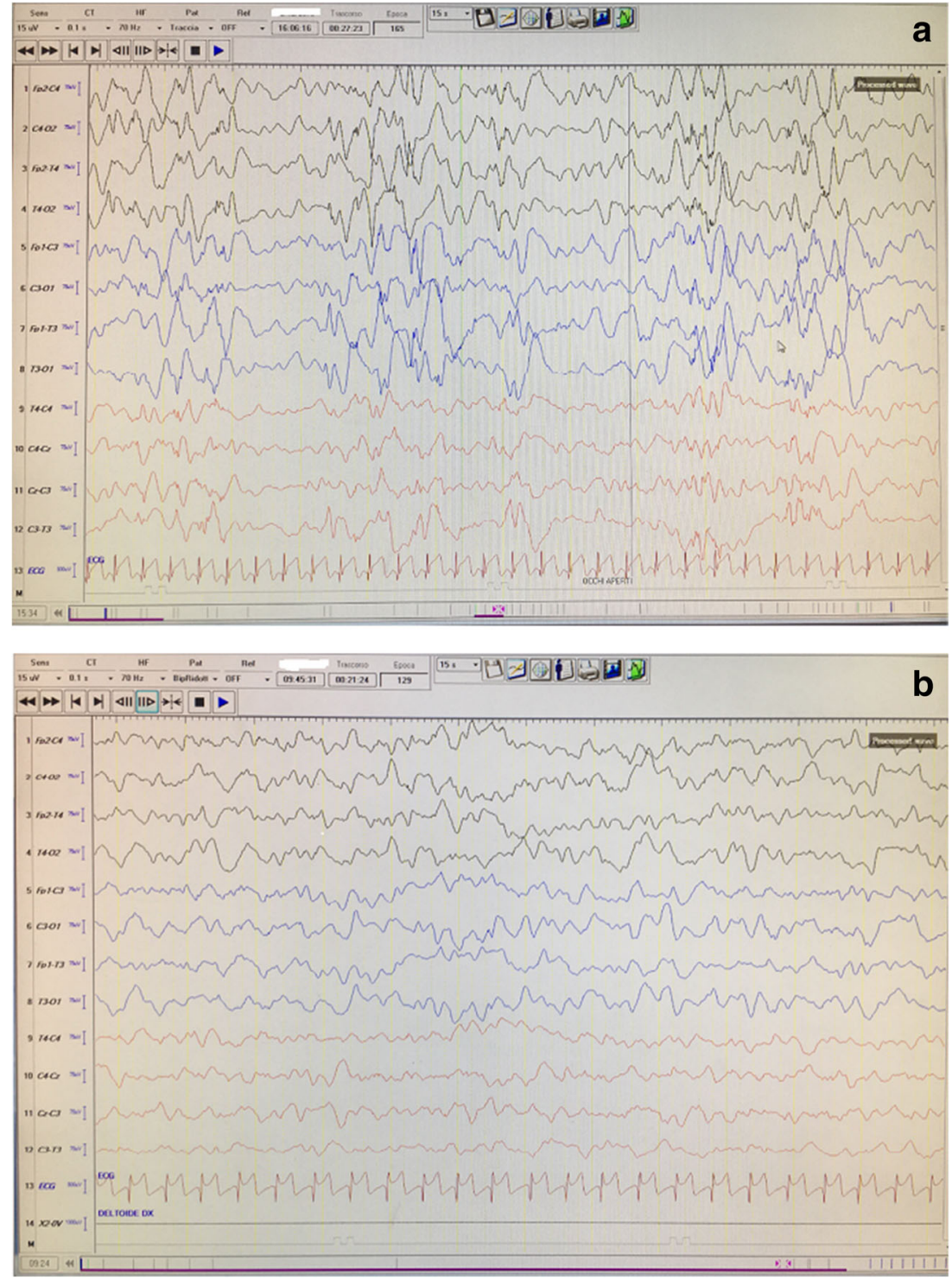

produce a marked reduction of seizure in about $45 \%$ of affected children $[119,120]$.

Several classical and novel antiepileptic drugs have been proposed for treating ISs. The most common and effective drugs include nitrazepam, levetiracetam, sodium valproate, topiramate, zonisamide, rufinamide, clobazam, perampanel, and vigabatrim (VGB), used as monotherapy or in variable combinations [120]. Among these drugs, some are of more recent introduction in ISs treatment protocols and thus clear results has not yet been achieved. Monotherapy achieved fair good results in about $20-40 \%$ of patients [11]. VGB is widely used in the treatment of ISs. VGB is generally used at starting dosage of $50 \mathrm{mg} / \mathrm{kg} /$ day up to $150 \mathrm{mg} / \mathrm{kg} /$ day. In a study conducted in 221 ISs patients, treatment with low doses (18$36 \mathrm{mg} / \mathrm{kg} /$ day) was compared with treatment with high doses $(100-148 \mathrm{mg} / \mathrm{kg} / \mathrm{day})$ : spasms cessation were obtained in the group receiving high doses in $15.9 \%$ of cases vs $7 \%$ of patients with low doses $(P=0375)$ : good EEG resolution was obtained in $30.8 \%$ in the group receiving high doses vs $13.2 \%$ of those with low doses [121]. Retinal toxicity is the most feared adverse effects of VGB, which is reported to occur in 21-34\% of infants treated with this drug when treatment is prolonged for more than 6 months. More recently, this drug has been associated to reversible and asymptomatic signal changes in the thalami, basal ganglia, brainstem tegmentum and cerebellar nuclei at brain imaging [122]: these signal abnormalities have been named "VGB-associated brain abnormalities" (VABAM). Hussain et al. [123] by analyzing brain MR images of 257 ISs children found asymptomatic VABAM in 6/40 children treated with VGB: he hypothesized that the signal abnormalities were related to combination of high doses of VGB and the concomitant hormonal treatment. In patients taking low doses of VGB, no brain MR anomalies were recorded. However, a combination of ACTH and VGB has been demonstrated to be effective 
in reducing ISs and in improving the EEG anomalies [124, 125]. In a cohort of 66 children with ISs treated with VGB at progressive doses - from $50 \mathrm{mg} / \mathrm{kg} /$ day to $150 \mathrm{mg} / \mathrm{kg} / \mathrm{day}$ and high doses of prednisolone (60 mg/kg/day), 22/66 (33\%) showed remission of spasms and a BASED score of $<2$ after VGB alone; while 26 (39.4\%) showed remission of spasms and a BASED score $<2$ after the association of VGB and prednisolone [126]. In a report by the International Collaborative Infantile Spasms Study (ICISS), VGB in association with hormonal treatment vs. hormonal therapy alone did not result in improved developmental or epilepsy outcomes at 18 months [110]. Recently, a treatment with a VGB analogue 3-amino-4difluoromethylenyl-1-cyclopentanoic acid (CCP-115) has been proposed in a 1-year-old ISs patient as an alternative treatment to VGB [127].

A single center, retrospective study was conducted in 24 patients with ISs: 10 patients were treated in monotherapy with sodium valproate (VPA); other 10 in association with clonazepam and 4 in association with nitrazepam: complete cessation rate and a 50\% reduction of spasms were obtained in $45.8 \%$ of patients [128]. The duration to complete cessation of spasms was 70 days whilst relapses occurred in $18.2 \%$ [128]. Developmental delay has been recently reported in patients treated with VPA and has been related to the long use of the drug. Acute liver failure after VPA exposure has been associated to patients who present DNA-polymerase gene (POLG) mutations [129].

The importance of a second treatment after initial failure has been confirmed by a multicenter prospective study by Knupp et al. [130] who report a good result in one third of children with ISs after the use of a second medication. The efficacy of a second treatment in children with ISs is maintained to be linked to a different mechanism of action of the second drug. In our institution, we are used to start treatment with ACTH $3 \mathrm{UI} / \mathrm{kg} / \mathrm{day}$ associated to VGB $50 \mathrm{mg} / \mathrm{kg} / \mathrm{day}$. The treatment with ACTH is stopped after 3 weeks while treatment with VGB is continued for about 6 months, and subsequently shifted with VPA or other antiepileptic drugs. Cannabinoid treatment for epileptic seizures has received careful interest [131]. At the moment no clear results about the efficacy and long-term safety in ISs patients have been reported [132].

Surgery treatment for ISs is rarely indicated and may be performed when well-documented focal epileptogenesis is recognized and when pharmacologic treatment has failed. Surgery treatment for ISs is one of attractive alternative in children with focal structural lesion. Surgical intervention is indicated when focal epileptogenesis is well documented through MRI, PET scan investigation in concordance to EEG abnormalities and when pharmacologic treatment has failed [108]. Treatment strategy for ISs have not changed so much during the last two decades. Standard first-line treatment with ACTH or prednisolone, and VGB, alone or in combination remains the most followed regime of treatment [17, 133-135].

\section{Specific emergent antiepileptic therapies in IS}

Genetic researches are running for targeted drug therapies proposed for correcting the underlying molecular/cellular dysfunction. At the moment, there is a number of trials including rapamycin/everolimus, targeting the mTOR pathway, for the treatment of TSC1/TSC2 [136]; memantine, targeting the actin protein GRIN2 A (NMDA) receptor [137]; and Retigabine (ezogabine) for the treatment of voltage-gated potassium channel $(K C N Q 2)$-related ISs, caused by ring chromosome 20 abnormalities [138].

\section{Clinical outcome}

In most patients, developmental delay, ranging from mild to severe degrees occurs prior to the onset of IS or, sometimes, may be concurrent or may follow the first ictal events. It must be noted, however, that it is not easy to recognize the delay at such early ages. Hypotonia, abnormal archaic reflexes, lethargy, poor reactivity may be clinical signs preceding the onset of IS: all these developmental features are strictly related to the serial epileptic seizures and to background molecular/cellular pathogenic events causing the ISs phenotype. Results of intellectual outcome at adult age in a cohort of 147 subjects affected by ISs according to conventional psychological test or based on educational status gave the following results: 25 children attended school normally with intelligence quotient (IQ) more than $85 ; 11$ were slightly impaired with IQ 68 to 85 ; 36 with mild learning disability and IQ 40 to $60 ; 75$ with severe impairment with IQ less than 40 [139, 140]. Association of ISs and autism spectrum disorder (ASD) has been frequently reported. Features compatible with ASD were historically observed in the West' son at his older age [11, 15, 141]. In a meta-analysis study of Strasser et al. [142] ASD was reported in $19.9 \%$ in subjects with ISs compared to $4.7 \%$ of other types of epilepsy. ASD was diagnosed in $33(13 \%)$ out 214 subjects with ISs [143]. In the group of 147 subjects a long time follow up 20-35 years after the IS a remission of the seizures was reported in a third of cases, a third had seizures with a daily or monthly frequency, and in the remaining third the seizures occurred with less frequency [140-144]. In a study of Krijgh et al. [145], at 8 weeks and 1 year of followup of 162 subjects $64(40 \%)$ were seizure free. IS tend to disappear within 3 to 4 years of age and transition from IS to Lennox-Gastaut syndrome is reported to occur in $18 \%$ of cases $[139,140]$. Fatal evolution was reported in $13 \%$ of the cases by Granstrom [146] and by Riikonen in a series of 214 children with ISs [147]. 


\section{Prognosis}

Several factors influence the outcome of children with ISs. Poor response to treatment, evolution towards other epileptic syndromes, the degree of developmental delay and intellectual disability, behavioral disturbances including autism spectrum disorders, general clinical impairment, worsening secondary to side effects of treatment. The recurrence of seizures is regarded as a negative factor for poor prognosis leading to intellective disability [6, 7]. All the above factors could certainly contribute to a poorer outcome, however, according to our personal experience and opinion and to literature review, major negative effects in the prognosis of ISs are related to the underlying (molecular/cellular) etiological event causing the syndrome [148]. According to GulMert et al. [149], the most relevant prognostic factors are the etiology, the age at the time of presentation, and late and inappropriate treatments. Outcome is usually poor in cases of ISs related to severe brain malformations, post infectious diseases, and primary genetic causes [140]. Until now, the efficacy of treatment in ISs is limited, in most cases, when the pathogenic/etiologic event is severe. Targeted genetic treatments represent a future hope for a severe condition such as ISs.

\section{Conclusions and future directions}

WS has evolved in each of the several aspects manifested by the patients affected by this severe disorder. Since the first report by West [1] several studies have been carried out aimed to solve the numerous enigma which this disorder hides. Many questions remain unclear and unsolved and suggest steps forward. Great advances have been obtained in the field of genetics which has allowed to identify new etiologic factors. Combined therapy has shown to give quit good results. In a next future the development of new therapies based on new or old molecules and the advances in molecular targeted therapy may represent the best way to avoid the harmful effects of this severe disorder.

Acknowledgments Open access funding provided by Università degli Studi di Catania within the CRUI-CARE Agreement. We wish to thank Prof. Rosemary Ready (Senior lecturer in English, University of Catania, Italy) for editing the final draft of the manuscript.

\section{Compliance with ethical standards}

Conflict of interest Authors declare that they have no conflicts of interest.

Statement of ethics The authors have no ethical conflicts to disclose.

Ethical approval None.
Open Access This article is licensed under a Creative Commons Attribution 4.0 International License, which permits use, sharing, adaptation, distribution and reproduction in any medium or format, as long as you give appropriate credit to the original author(s) and the source, provide a link to the Creative Commons licence, and indicate if changes were made. The images or other third party material in this article are included in the article's Creative Commons licence, unless indicated otherwise in a credit line to the material. If material is not included in the article's Creative Commons licence and your intended use is not permitted by statutory regulation or exceeds the permitted use, you will need to obtain permission directly from the copyright holder. To view a copy of this licence, visit http://creativecommons.org/licenses/by/4.0/.

\section{References}

1. West WJ (1841) On a peculiar form of infantile convulsions. Lancet 35:724-725

2. Commission on Classification and Terminology of the International League Against Epilepsy (1989) Proposal for revised classification of epilepsies and epileptic syndromes. Epilepsia 30:389-399

3. Commission on Classification and Terminology of the International League Against Epilepsy (1992) Workshop on infantile spasms. Epilepsia 33:195

4. Lux AL, Osborne JP (2004) A proposal for case definitions and outcome measures in studies of infantile spasms and West syndrome: consensus statement of the West Delphi group. Epilepsia 45:1416-1428

5. Fisher RS, Cross JH, French JA, Higurashi N, Hirsch E, Jansen FE, Lagae L, Moshé SL, Peltola J, Roulet Perez E, Scheffer IE, Zuberi SM (2017) Operational classification of seizure types by the international league against epilepsy: position paper of the ILAE Commission for Classification and Terminology. Epilepsia 58:522-530

6. Scheffer IE, Berkovic S, Capovilla G, Connolly MB, French J, Guilhoto L, Hirsch E, Jain S, Mathern GW, Moshé SL, Nordli DR, Perucca E, Tomson T, Wiebe S, Zhang YH, Zuberi SM (2017) ILAE classification of the epilepsies: position paper of the ILAE Commission for Classification and Terminology. Epilepsia 58:512-521

7. Mackay MT, Weiss SK, Adams-Webber T, Ashwal S, Stephens D, Ballaban-Gill K, Baram TZ, Duchowny M, Hirtz D, Pellock JM, Shields WD, Shinnar S, Wyllie E, Snead OC 3rd, American Academy of Neurology, Child Neurology Society (2004) Practice parameter: medical treatment of infantile spasms: report of the American Academy of Neurology and the Child Neurology Society. Neurology 62:1668-1681

8. Berg AT, Berkovic SF, Brodie MJ, Buchhalter J, Cross JH, van Emde Boas W, Engel J, French J, Glauser TA, Mathern GW, Moshé SL, Nordli D, Plouin P, Scheffer IE (2010) Revised terminology and concepts for organization of seizures and epilepsies: report of the ILAE commission on classification and terminology, 2005-2009. Epilepsia 51:676-685

9. Caraballo RH, Ruggieri V, Gonzalez G, Cersósimo R, Gamboni B, Rey A, Poveda JC, Dalla Bernardina B (2011) Infantile spams without hypsarrhythmia: a study of 16 cases. Seizure 20:197-202

10. Jia JL, Chen S, Sivarajah V, Stephens D, Cortez MA (2018) Latitudinal differences on the global epidemiology of infantile spasms: systematic review and meta-analysis. Orphanet J Rare Dis 13(1):216. https://doi.org/10.1186/s13023-018-0952-x

11. Lux AL (2013) Latest American and European updates on infantile spasms. Curr Neurol Neurosci Rep 13:334-341 
12. Riikonen R, Donner M (1979) Incidence and aetiology of infantile spasms from 1960 to 1976: a population study in Finland. Dev Med Child Neurol 21(3):333-343

13. Yuskaitis CJ, Ruzhnikov MRZ, Howell KB, Allen IE, Kapur K, Dlugos DJ, Scheffer IE, Poduri A, Sherr EH (2018) Infantile spasms of unknown cause: predictors of outcome and genotype-phenotype correlation. Pediatr Neurol pii S0887-8994(18):30346-30341

14. Osborne JP, Lux AL, Edwards SW, Hancock E, Johnson AL, Kennedy CR, Newton RW, Verity CM, O'Callaghan FJ (2010) The underlying etiology of infantile spasms (West syndrome): information from the United Kingdom infantile spasms study (UKISS) on contemporary causes and their classification. Epilepsia 51:2168-2174

15. Pavone P, Striano P, Falsaperla R, Pavone L, Ruggieri M (2014) Infantile spasms syndrome, West syndrome and related phenotypes: what we know in 2013. Brain Dev 36:739-751

16. Paciorkowski AR, Thio LL, Dobyns WB (2011) Genetic and biologic classification of infantile spasms. Pediatr Neurol 45:355-367

17. Wirrell EC, Shellhaas RA, Joshi C, Keator C, Kumar S, Mitchell WG (2015) How should children with West syndrome be efficiently and accurately investigated? Results from the National Infantile Spasms Consortium. Epilepsia 56:617-625

18. Dulac O, Feingold J, Plouin P, Chiron C, Pajot N, Ponsot G (1993) Genetic predisposition to West syndrome. Epilepsia 34:732-737

19. Hemminki K, Li X, Johansson SE, Sundquist K, Sundquist J (2006) Familial risks for epilepsy among siblings based on hospitalizations in Sweden. Neuroepidemiology 27:67-73

20. Pavone L, Mollica F, Incorpora G, Pampiglione G (1985) Infantile spasms syndrome in monozygotic twins. A 7-year follow-up. Ital J Neurol Sci 6:503-506

21. Coppola G, Grosso S, Verrotti A, D'Aniello A, Pascotto A (2010) Simultaneous onset of infantile spasms in monozygotic twins. Pediatr Neurol 43:127-130

22. Kato M, Das S, Petras K, Sawaishi Y, Dobyns WB (2003) Polyalanine expansion of ARX associated with cryptogenic West syndrome. Neurology 61:267-276

23. Wallerstein R, SugalskiR, Cohn L, JawetzR, FriezM(2008)Expansion of the ARX spectrum. Clin Neurol Neurosurg 110:631-634

24. Guerrini R, Filippi T (2005) Neuronal migration disorders, genetics, and epileptogenesis. J Child Neurol 20:287-299

25. Weaving LS, Christodoulou J, Williamson SL, Friend KL, McKenzie OLD, Archer H, Evans J, Clarke A, Pelka GJ, Tam PPL, Watson C, Lahooti H, Ellaway CJ, Bennetts B, Leonard H, Gécz J (2004) Mutations of CDKL5 cause a severe neurodevelopmental disorder with infantile spasms and mental retardation. Am J Hum Genet 75:1079-1093

26. Elia M, Falco M, Ferri R, Spalletta A, Bottitta M, Calabrese G, Carotenuto M, Musumeci SA, Lo Giudice M, Fichera M (2008) CDKL5 mutations in boys with severe encephalopathy and earlyonset intractable epilepsy. Neurology 71:997-999

27. Masliah-Plachon J, Auvin S, Nectoux J, Fichou Y, Chelly J, Bienvenu T (2010) Somatic mosaicism for a CDKL5 mutation as an epileptic encephalopathy in males. Am J Med Genet A 152:2110-2111

28. Deprez L, Weckhuysen S, Holmgren P, Suls A, van Dyck T, Goossens D, del-Favero J, Jansen A, Verhaert K, Lagae L, Jordanova A, van Coster R, Yendle S, Berkovic SF, Scheffer I, Ceulemans B, de Jonghe P (2010) Clinical spectrum of early-onset epileptic encephalopathies associated with STXBP1 mutations. Neurology 75:1159-1165

29. Saitsu H, Kato M, Okada I, Orii KE, Higuchi T, Hoshino H, Kubota M, Arai H, Tagawa T, Kimura S, Sudo A, Miyama S, Takami Y, Watanabe T, Nishimura A, Nishiyama K, Miyake N, Wada T, Osaka H, Kondo N, Hayasaka K, Matsumoto N (2010) STXBP1 mutations in early infantile epileptic encephalopathy with suppression-burst pattern. Epilepsia 51:2397-2405
30. Kato M, Yamagata T, Kubota M, Arai H, Yamashita S, Nakagawa T, FujII T, Sugai K, Imai K, Uster T, Chitayat D, Weiss S, Kashii H, Kusano R, Matsumoto A, Nakamura K, Oyazato Y, Maeno M, Nishiyama K, Kodera H, Nakashima M, Tsurusaki Y, Miyake N, Saito K, Hayasaka K, Matsumoto N, Saitsu H (2013) Clinical spectrum of early onset epileptic encephalopathies caused by KCNQ2 mutation. Epilepsia 54:1282-1287

31. Lemke JR, Hendrickx R, Geider K, Laube B, Schwake M, Harvey RJ, James VM, Pepler A, Steiner I, Hörtnagel K, Neidhardt J, Ruf S, Wolff M, Bartholdi D, Caraballo R, Platzer K, Suls A, de Jonghe P, Biskup S, Weckhuysen S (2014) GRIN2B mutations in West syndrome and intellectual disability with focal epilepsy. Ann Neurol 75:147-154

32. Boutry-Kryza N, Labalme A, Ville D, de Bellescize J, Touraine R, Prieur F, Dimassi S, Poulat AL, Till M, Rossi M, Bourel-Ponchel $\mathrm{E}$, Delignières A, le Moing AG, Rivier $\mathrm{C}$, des Portes V, Edery P, Calender A, Sanlaville D, Lesca G (2015) Molecular characterization of a cohort of 73 patients with infantile spasms syndrome. Eur J Med Genet 58:51-58

33. Marshall CR, Young EJ, Pani AM, Freckmann ML, Lacassie Y, Howald C, Fitzgerald KK, Peippo M, Morris CA, Shane K, Priolo M, Morimoto M, Kondo I, Manguoglu E, Berker-Karauzum S, Edery P, Hobart HH, Mervis CB, Zuffardi O, Reymond A, Kaplan P, Tassabehji M, Gregg RG, Scherer SW, Osborne LR (2008) Infantile spasms is associated with deletion of the MAGI2 gene on chromosome 7q11.23-q21.11. Am J Hum Genet 83:106-111

34. Morikawa M, Takano K, Motobayashi M, Shiba N, Kosho T, Nakazawa Y, Inaba Y (2017) Clinical features of a female with WDR45 mutation complicated by infantile spasms: a case report and literature review. Brain and Development 39:804-807

35. Nakashima M, Takano K, Tsuyusaki Y, Yoshitomi S, Shimono M, Aoki Y, Kato M, Aida N, Mizuguchi T, Miyatake S, Miyake N, Osaka H, Saitsu H, Matsumoto N (2016) WDR45 mutations in three male patients with West syndrome. J Hum Genet 61:653-661

36. Millichap JJ, Miceli F, De Maria M et al (2017) Infantile spasms and encephalopathy without preceding neonatal seizures caused by KCNQ2 R198Q, a gain-of-function variant. Epilepsia 58:10 15

37. Conroy J, Allen NM, Gorman K, O'Halloran E, Shahwan A, Lynch B, Lynch SA, Ennis S, King MD (2016) Novel European SLC1A4 variant: infantile spasms and population ancestry analysis. J Hum Genet 61:761-764

38. Ngoh A, Bras J, Guerreiro R, Meyer E, McTague A, Dawson E, Mankad K, Gunny R, Clayton P, Mills PB, Thornton R, Lai M, Forsyth R, Kurian MA (2016) RARS2 mutations in a sibship with infantile spasms. Epilepsia 57:e97-e102

39. Daida A, Hamano SI, Ikemoto S, Matsuura R, Nakashima M, Matsumoto N, Kato M (2018) Biallelic loss-of-function UBA5 mutations in a patient with intractable West syndrome and profound failure to thrive. Epileptic Disord 20:313-318

40. Takezawa Y, Fujie H, Kikuchi A, Niihori T, Funayama R, Shirota M, Nakayama K, Aoki Y, Sasaki M, Kure S (2018) Novel IARS2 mutations in Japanese siblings with CAGSSS, Leigh, and West syndrome. Brain and Development 40:934-938

41. Jdila MB, Triki C, Rhouma BB, Jomaa RB, Issa AB, AmmarKeskes L, Kamoun F, Fakhfakh F (2019) A novel C-terminal truncated mutation in hCDKL5 protein causing a severe West syndrome: comparison with previous truncated mutations and genotype/phenotype correlation. Int J Dev Neurosci 72:22-30

42. Hamada N, Ogaya S, Nakashima M, Nishijo T, Sugawara Y, Iwamoto I, Ito H, Maki Y, Shirai K, Baba S, Maruyama K, Saitsu H, Kato M, Matsumoto N, Momiyama T, Nagata KI (2018) De novo PHACTR1 mutations in West syndrome and their pathophysiological effects. Brain 141:3098-3114

43. Peng J, Wang Y, He F, Chen C, Wu LW, Yang LF, Ma YP, Zhang W, Shi ZQ, Chen C, Xia K, Guo H, Yin F, Pang N (2018) Novel 
West syndrome candidate genes in a Chinese cohort. CNS Neurosci Ther 24:1196-1206

44. Shimojima K, Okamoto N, Ohmura K, Nagase H, Yamamoto T (2018) Infantile spasms related to a 5q31.2-q31.3 microdeletion including PURA. Hum Genome Var 5:18007

45. Reijnders MRF, Janowski R, Alvi M, Self JE, van Essen TJ, Vreeburg M, Rouhl RPW, Stevens SJC, Stegmann APA, Schieving J, Pfundt R, van Dijk K, Smeets E, Stumpel CTRM, Bok LA, Cobben JM, Engelen M, Mansour S, Whiteford M, Chandler KE, Douzgou S, Cooper NS, Tan EC, Foo R, Lai AHM, Rankin J, Green A, Lönnqvist T, Isohanni P, Williams S, Ruhoy I, Carvalho KS, Dowling JJ, Lev DL, Sterbova K, Lassuthova P, Neupauerová J, Waugh JL, Keros S, ClaytonSmith J, Smithson SF, Brunner HG, van Hoeckel C, Anderson M, Clowes VE, Siu VM, DDD study T, Selber P, Leventer RJ, Nellaker C, Niessing D, Hunt D, Baralle D (2018) PURA syndrome: clinical delineation and genotype-phenotype study in 32 individuals with review of published literature. J Med Genet 55: 104-113

46. Neville BG (1972) The origin of infantile spasms: evidence from a case of hydranencephaly. Dev Med Child Neurol 14:644-647

47. Tian G, Cristancho AG, Dubbs HA, Liu GT, Cowan NJ, Goldberg EM (2016) A patient with lissencephaly, developmental delay, and infantile spasms, due to de novo heterozygous mutation of KIF2A. Mol Genet Genomic Med 4:599-603

48. Jones K, Weiss SK, Minassian B (2016) Infantile spasms with periventricular nodular heterotopia, unbalanced chromosomal translocation 3p26.2 -10p15.1 and 6q22.31 duplication. Clin Case Rep 4:675-677

49. Al Dhaibani MA, El-Hattab AW, Ismayl O, Suleiman J (2018) B3GALNT2-related dystroglycanopathy: expansion of the phenotype with novel mutation associated with muscle-eye-brain disease, Walker-Warburg syndrome, epileptic encephalopathy-West syndrome, and sensorineural hearing loss. Neuropediatrics 49: 289-295

50. Romano C, Tiné A, Fazio G, Rizzo R, Colognola RM, Sorge G, Bergonzi P, Pavone L (1990) Seizures in patients with trisomy 21. Am J Med Genet Supplement 7:298-300

51. Tapp S, Anderson T, Visootsak J (2015) Neurodevelopmental outcomes in children with down syndrome and infantile spasms. J Pediatr Neurol 13:74-77

52. Cerminara C, Compagnone E, Bagnolo V, Galasso C, Lo-Castro A, Brinciotti M, Curatolo P (2010) Late-onset epileptic spasms in children with Pallister-Killian syndrome: a report of two new cases and review of the electroclinical aspects. J Child Neurol 25:238245

53. Lin CH, Lin WD, Chou IC, Lee IC, Fan HC, Hong SY (2018) Epileptic spasms in PPP1CB-associated Noonan-like syndrome: a case report with clinical and therapeutic implications. BMC Neurol 18:150

54. Anttonen AK, Laari A, Kousi M, Yang YJ, Jääskeläinen T, Somer M, Siintola E, Jakkula E, Muona M, Tegelberg S, Lönnqvist T, Pihko H, Valanne L, Paetau A, Lun MP, Hästbacka J, Kopra O, Joensuu T, Katsanis N, Lehtinen MK, Palvimo JJ, Lehesjoki AE (2017) ZNHIT3 is defective in PEHO syndrome, a severe encephalopathy with cerebellar granule neuron loss. Brain 140:12671279

55. Trifiletti RR, Incorpora G, Polizzi A, Cocuzza MD, Bolan EA, Parano E (1995) Aicardi syndrome with multiple tumors: a case report with literature review. Brain \& Develop 17:283-285

56. Al Hafid N, Christodoulou J (2015) Phenylketonuria: a review of current and future treatments. Transl Pediatr 4:304-317

57. Alrifai MT, AlShaya MA, Abulaban A, Alfadhel M (2014) Hereditary neurometabolic causes of infantile spasms in 80 children presenting to a tertiary care center. Pediatr Neurol 51:390-397
58. Gullotta F, Pavone L, Mollica F, Grasso S, Valenti C (1979) Krabbe's disease with unusual clinical and morphological features. Neuropadiatrie 10:395-400

59. Tanzi RE, Petrukhin K, Chernov I, Pellequer JL, Wasco W, Ross B, Romano DM, Parano E, Pavone L, Brzustowicz LM, Devoto M, Peppercorn J, Bush AI, Sternlieb I, Pirastu M, Gusella JF, Evgrafov O, Penchaszadeh GK, Honig B, Edelman IS, Soares MB, Scheinberg IH, Gilliam TC (1993) The Wilson disease gene is a copper transporting ATPase with homology to the Menkes disease gene. Nat Genet 5:344-350

60. Smpokou P, Samanta M, Berry GT, Hecht L, Engle EC, LichterKonecki U (2015) Menkes disease in affected females: the clinical disease spectrum. Am J Med Genet A 167A:417-420

61. Larson A, Weisfeld-Adams JD, Benke TA, Bonnen PE (2017) Cerebrotendinous xanthomatosis presenting with infantile spasms and intellectual disability. JIMD Rep 35:1-5

62. Lee HH, Hur YJ (2016) Glucose transport 1 deficiency presenting as infantile spasms with a mutation identified in exon 9 of SLC2A1. Korean J Pediatr 59(Suppl 1):S29-S31

63. Pereira AG, Bahi-Buisson N, Barnerias C, Boddaert N, Nabbout R, de Lonlay P, Kaminska A, Eisermann M (2017) Epileptic spasms in congenital disorders of glycosylation. Epileptic Disord 19:15-23

64. van Karnebeek CD, Tiebout SA, Niermeijer J et al (2016) Pyridoxine-dependent epilepsy: an expanding clinical spectrum. Pediatr Neurol 59:6-12

65. Gospe SM Jr. In: Adam MP, Ardinger HH, Pagon RA, Wallace SE (2001) Bean LIH, Stephens K, Amemiya A. Pyridoxinedependent epilepsy. Seattle (WA) editors. University of Washington Seattle; GeneReviews 1993-2017. 7:1-36

66. Ruggieri M, Pascual-Castroviejo I, Di Rocco C (2008) Neurocutaneous disorders. Phakomatoses and Hamartoneoplastic Syndromes, Wien/New York, Springer

67. Islam MP, Roach ES (2015) Neurocutaneous syndromes. Handbook of Clinical neurology: 3rd Series No 132 New York, Elsevier

68. Ruggieri M, Praticò AD (2015) Mosaic neurocutaneous disorders and their causes. Semin Pediatr Neurol 22:207-233

69. Curatolo P, Bombardieri R, Jozwiak S (2008) Tuberous sclerosis. Lancet 372:657-668

70. Chu-Shore CJ, Major P, Camposano S, Muzykewicz D, Thiele EA (2010) The natural history of epilepsy in tuberous sclerosis complex. Epilepsia 51:1236-1241

71. Curatolo P, Moavero R, van Scheppingen J, Aronica E (2018) mTOR dysregulation and tuberous sclerosis-related epilepsy. Expert Rev Neurother 18:185-201

72. de Vries PJ, Wilde L, de Vries MC, Moavero R, Pearson DA, Curatolo P (2018) A clinical update "tuberous sclerosis" complex-associated neuropsychiatric disorders (TAND). Am J Med Genet C Semin Med Genet 178:309-320

73. Wilbur C, Sanguansermsri C, Chable H, Anghelina M, Peinhof S (2017) Manifestations of tuberous sclerosis complex: the experience of a provincial clinic. Can J Neurol Sci 44:35-43

74. Song J, Swallow E, Said Q, Peeples M, Meiselbach M, Signorovitch J, Kohrman M, Korf B, Krueger D, Wong M, Sparagana S (2018) Epilepsy treatment patterns among patients with tuberous sclerosis complex. J Neurol Sci 391:104-108

75. Fohlen M, Taussig D, Ferrand-Sorbets S, Chipaux M, Dorison N, Delalande O, Dorfmüller G (2018) Refractory epilepsy in preschool children with tuberous sclerosis complex: early surgical treatment and outcome. Seizure 60:71-79

76. Ji S, Lin W, Wang L, Ni Z, Jin F, Zha X, Fei G (2017) Combined targeting of mTOR and Akt using rapamycin and MK-2206 in the treatment of tuberous sclerosis complex. Cancer 8:555-562

77. Franz DN, Lawson JA, Yapici Z, Ikeda H, Polster T, Nabbout R, Curatolo P, de Vries PJ, Dlugos DJ, Voi M, Fan J, Vaury A, Pelov 
D, French JA (2018) Everolimus for treatment-refractory seizures in TSC: extension of a randomized controlled trial. Neurol Clin Pract 8:412-420

78. Curatolo P, Franz DN, Lawson JA, Yapici Z, Ikeda H, Polster T, Nabbout R, de Vries PJ, Dlugos DJ, Fan J, Ridolfi A, Pelov D, Voi M, French JA (2018) Adjunctive everolimus for children and adolescents with treatment-refractory seizures associated with tuberous sclerosis complex: post-hoc analysis of the phase 3 EXIST-3 trial. Lancet Child Adolesc Health 2:495-504

79. Ruggieri M (1999) The different forms of neurofibromatosis. Child Nerv Syst 15:295-308

80. Monroe CL, Dahiya S, Gutmann DH (2017) Dissecting clinical heterogeneity in neurofibromatosis type 1. Annu Rev Pathol 12: 53-57

81. Hsieh HY, Fung HC, Wang CJ, Chin SC, Wu T (2011) Epileptic seizures in neurofibromatosis type 1 are related to intracranial tumors but not to neurofibromatosis bright objects. Seizure 20: 606-611

82. Ruggieri M, Iannetti P, Clementi M, Polizzi A, Incorpora G, Spalice A, Pavone P, Praticò AD, Elia M, Gabriele AL, Tenconi R, Pavone L (2009) Neurofibromatosis type 1 and infantile spasms. Childs Nerv Syst 25:211-216

83. Comi AM (2011) Presentation, diagnosis, pathophysiology, and treatment of the neurological features of Sturge-Weber syndrome. Neurologist. 17:179-184

84. Shirley MD, Tang H, Gallione CJ, Baugher JD, Frelin LP, Cohen B, North PE, Marchuk DA, Comi AM, Pevsner J (2013) SturgeWeber syndrome and port-wine stains caused by somatic mutation in GNAQ. N Engl J Med 368:1971-1979

85. Turin E, Grados MA, Tierney E, Ferenc LM, Zabel A, Comi AM (2010) Behavioral and psychiatric features of Sturge-weber syndrome. J Nerv Ment Dis 198:905-913

86. Raches D, Hiscock M, Chapieski L (2012) Behavioral and academic problems in children with Sturge-Weber syndrome: differences between children with and without seizures. Epilepsy Behav 25:457-463

87. Barbagallo $\mathrm{M}$, Ruggieri $\mathrm{M}$, Incorpora $\mathrm{G}$, Pavone $\mathrm{P}$, Nucifora $\mathrm{C}$, Spalice A, Praticò AD, Polizzi A, Pavone L, Iannetti P (2009) Infantile spasms in the setting of Sturge-Weber syndrome. Childs Nerv Syst 25:111-118

88. Ruggieri M, Pavone L (2000) Hypomelanosis of Ito: clinical syndrome or just phenotype? J Child Neurol 15:635-644

89. Pavone P, Praticò AD, Ruggieri M, Falsaperla R (2015) Hypomelanosis of Ito: a round on the frequency and type of epileptic complications. Neurol Sci 36:1173-1180

90. Ruggieri M, Tigano G, Mazzone D, Tinè A, Pavone L (1996) Involvement of the white matter in hypomelanosis of Ito (incontinentia pigmenti achromiens). Neurology 45:485-492

91. Shandra O, Moshé SL, Galanopoulou AS (2017) Inflammation in epileptic encephalopathies. Adv Protein Chem Struct Biol 108: $59-84$

92. Suleiman J, Brenner T, Gill D et al (2011) Immune-mediated steroid-responsive epileptic spasms and epileptic encephalopathy associated with VGKC-complex antibodies. Dev Med Child Neurol 53:1058-1060

93. Dulac O (2001) What is West syndrome? Brain and Development 23:447-452

94. Wilmshurst JM, Ibekwe RC, O'Callaghan FJK (2017) Epileptic spasms -175 years on: trying to teach an old dog new tricks. Seizure 44:81-86

95. Appleton RE (2015) Investigations in West syndrome: which, when and why. Pediatr Neurol Briefs 29:42

96. Chong PF, Saitsu H, Sakai Y, Imagi T, Nakamura R, Matsukura M, Matsumoto N, Kira R (2018) Deletions of SCN2A and SCN3A genes in a patient with West syndrome and autistic spectrum disorder. Seizure 60:91-93
97. Jeavons PM (1985) West syndrome: infantile spasms in epileptic syndrome in infancy, childhood and adolescence. Roger S, Dravet C, Bureau M, Dreifuss FE and Wolf P. Libbey Eurotext J LTD Ed. pp42-50

98. Aicardi J, Chevrie JJ (1978) Les spasms infantiles. Arch Fr Pédiatr 35:1015-1023

99. Saporito MAN, Vitaliti G, Pavone P, Di Stefano G, Striano P, Caraballo RH, Falsaperla R (2017) Ictal blinking, an underrecognized phenomenon: our experience and literature review. Neuropsychiatr Dis Treat 13:1435-1439

100. Hussain SA, Lay J, Cheng E, Weng J, Sankar R, Baca CB (2017) Recognition of infantile spasms is often delayed: the ASSIST study. J Pediatr 190:215-221

101. Wang L, Yarosz S, Aghamoosa H, Grinspan Z, Patel AD (2018) Validating an algorithm to identify patients with infantile spasms using medical claims. J Child Neurol 33:639-641

102. Xue J, Qian P, Li H et al (2016) Atonic elements combined or uncombined with epileptic spasm in infantile spasms. Clin Neurophysiol 128:220-226

103. Caraballo RH, Fortini S, Reyes G (2016) Epileptic spasms in clusters and associated syndromes other than West syndrome: a study of 48 patients. Epilepsy Res 123:29-35

104. Caraballo RH, Falsaperla R, Gutierrez R, Reyes Valenzuela G, Pavone P, Fortini S, Pochada J (2017) Single-epileptic spasms with or without hypsarrhythmia: a study of 16 patients. Journal of Pediatric Epilepsy 123:149-155

105. Tarodo SG, Nguyen T, Ranza E, Vulliémoz S, Korff CM (2018) A triad of infantile spasms, nystagmus and a focal tonic seizure. Epileptic Disord 20:295-300

106. Falsaperla R, Marino SD, Marino S, Pavone P (2018) Electroclinical pattern and epilepsy evolution in an infant with Miller-Dieker syndrome. J Pediatr Neurosci 13:302-307

107. Berg AT, Chakravorty S, Koh S, Grinspan ZM, Shellhaas RA, Saneto RP, Wirrell EC, Coryell J, Chu CJ, Mytinger JR, Gaillard WD, Valencia I, Knupp KG, Loddenkemper T, Sullivan JE, Poduri A, Millichap JJ, Keator C, Wusthoff C, Ryan N, Dobyns WB, Hegde M (2018) Why West? Comparisons of clinical, genetic and molecular features of infants with and without spasms. PLoS One 13:e0193599

108. Nairai H, Beal J, Galanopoulou AS et al (2017) Scalp EEG Ictal gamma and beta activity during infantile spasms: evidence of focality. Epilepsia 58:882-892

109. Harini C, Sharda S, Bergin AM, Poduri A, Yuskaitis CJ, Peters JM, Rakesh K, Kapur K, Pearl PL, Prabhu SP (2018) Detailed magnetic resonance imaging (MRI) analysis in infantile spasms. J Child Neurol 33:405-412

110. O'Callaghan FJK, Edwards SW, Alber FD, Hancock E, Johnson AL, Kennedy CR, Likeman M, Lux AL, Mackay M, Mallick AA, Newton RW, Nolan M, Pressler R, Rating D, Schmitt B, Verity CM, Osborne JP, Participating investigators (2017) Safety and effectiveness of hormonal treatment versus hormonal treatment with vigabatrin for infantile spasms (ICISS): a randomised, multicentre, open-label trial. Lancet Neurol 16:33-42

111. Capal JK, Bernardino-Cuesta B, Horn PS, Murray D, Byars AW, Bing NM, Kent B, Pearson DA, Sahin M, Krueger DA, TACERN Study Group (2017) Influence of seizures on early development in tuberous sclerosis complex. Epilepsy Behav 70:245-252

112. Yin J, Lu Q, Yin F, Wang Y, He F, Wu L, Yang L, Deng X, Chen C, Peng J (2017) Effectiveness and safety of different once-daily doses of adrenocorticotropic hormone for infantile spasms. Paediatr Drugs 19:357-365

113. Shumiloff NA, Lam WM, Manasco KB (2013) Adrenocorticotropic hormone for the treatment of West syndrome in children. Ann Pharmacother 47:744-754 
114. D'Alonzo R, Rigante D, Mencaroni E, Esposito S (2018) West syndrome: a review and guide for paediatricians. Clin Drug Investig 38:113-124

115. Wanigasinghe J, Arambepola C, Ranganathan SS, Sumanasena S (2017) Randomized, single-blind, parallel clinical trial on efficacy of oral prednisolone versus intramuscular corticotropin: a 12month assessment of spasm control in West syndrome. Pediatr Neurol 76:14-19

116. Gowda VK, Narayanaswamy V, Shivappa SK, Benakappa N, Benakappa A (2019) Corticotrophin-ACTH in comparison to prednisolone in West syndrome - a randomized study. Indian J Pediatr 86(2):165-170

117. Kunnanayaka V, Jain P, Sharma S, Seth A, Aneja S (2018) Addition of pyridoxine to prednisolone in the treatment of infantile spasms: a pilot, randomized controlled trial. Neurol India 66:385-390

118. Kossoff EH (2010) Infantile spasms. Neurologist 16:69-75

119. Kossoff EH (2008) The modified Atkins diet. Epilepsia 49:37-41

120. Song JM, Hahn J, Kim SH, Chang MJ (2017) Efficacy of treatments for infantile spasms: a systematic review. Clin Neuropharmacol 40:63-84

121. Elterman RD, Shields WD, Bittman RM, Torri SA, Sagar SM, Collins SD (2010) Vigabatrin for the treatment of infantile spasms: final report of a randomized trial. J Child Neurol 25:1340-1347

122. Sun LR, Bosemani T, Smith-Hicks CL (2017) Neuroimaging abnormalities in a child with infantile spasms on high-dose vigabatrin. Pediatr Neurol 67:109-110

123. Hussain SA, Tsao J, Li M, Schwarz MD, Zhou R, Wu JY, Salamon N, Sankar R (2017) Risk of vigabatrin-associated brain abnormalities on MRI in the treatment of infantile spasms is dosedependent. Epilepsia 58:674-682

124. Iyer A, Appleton R (2016) Improving outcomes in infantile spasms: role of pharmacotherapy. Paediatr Drugs 18:357-366

125. Riikonen R (2017) Combination therapy for treatment of infantile spasms. Lancet Neurol 16:19-20

126. Ko A, Youn SE, Chung HJ, Kim SH, Lee JS, Kim HD, Kang HC (2018) Vigabatrin and high-dose prednisolone therapy for patients with West syndrome. Epilepsy Res 145:127-133

127. Doumlele K, Conway E, Hedlund J, Tolete P, Devinsky O (2016) A case report on the efficacy of vigabatrin analogue (1S, 3S)-3amino-4-difluoromethylenyl-1-cyclopentanoic acid (CPP-115) in a patient with infantile spasms. Epilepsy Behav Case Rep 6:67-69

128. Auvichayapat N, Tassniyom S, Treerotphon S, Auvichayapat P (2007) Treatment of infantile spasms with sodium valproate followed by benzodiazepines. J Med Assoc Thail 90:1809-1814

129. Hynynen J, Komulainen T, Tukiainen E, Nordin A, Arola J, Kälviäinen R, Jutila L, Röyttä M, Hinttala R, Majamaa K, Mäkisalo H, Uusimaa J (2014) Acute liver failure after valproate exposure in patients with POLG1 mutations and the prognosis after liver transplantation. Liver Transpl 20:1402-1412

130. Knupp KG, Leister E, Coryell J, Nickels KC, Ryan N, JuarezColunga E, Gaillard WD, Mytinger JR, Berg AT, Millichap J, Nordli DR Jr, Joshi S, Shellhaas RA, Loddenkemper T, Dlugos D, Wirrell E, Sullivan J, Hartman AL, Kossoff EH, Grinspan ZM, Hamikawa L, the Pediatric Epilepsy Research Consortium (2016) Response to second treatment after initial failed treatment in a multicenter prospective infantile spasms cohort. Epilepsia 57: 1834-1842

131. Mudigoudar B, Weatherspoon S, Wheless JW (2016) Emerging antiepileptic drugs for severe pediatric epilepsies. Semin Pediatr Neurol 23:167-179

132. Tibussek D, Klepper J, Korinthenberg R et al (2016) Treatment of infantile spasms: report of the interdisciplinary guideline committee coordinated by the German-speaking society for neuropediatrics. Neuropediatrics 47:139-150
133. Hamano SI, Nagai T, Matsuura R, Hirata Y, Ikemoto S, Oba A, Hiwatari E (2018) Treatment of infantile spasms by pediatric neurologists in Japan. Brain and Development 40:685-692

134. Demarest ST, Shellhaas RA, Gaillard WD, Keator C, Nickels KC, Hussain SA, Loddenkemper T, Patel AD, Saneto RP, Wirrell E, Sánchez Fernández I, Chu CJ, Grinspan Z, Wusthoff CJ, Joshi S, Mohamed IS, Stafstrom CE, Stack CV, Yozawitz E, Bluvstein JS, Singh RK, Knupp KG, the Pediatric Epilepsy Research Consortium (2017) The impact of hypsarrhythmia on infantile spasms treatment response: observational cohort study from the National Infantile Spasms Consortium. Epilepsia 58:2098-2103

135. Ohtsuka Y (2018) Efficacy and safety of vigabatrin in Japanese patients with infantile spasms: primary short-term study and extension study. Epilepsy Behav 78:134-141

136. Franz DN, Belousova E, Sparagana S, Bebin EM, Frost MD, Kuperman R, Witt O, Kohrman MH, Flamini JR, Wu JY, Curatolo P, de Vries PJ, Berkowitz N, Niolat J, Jóźwiak S (2016) Long-term use of everolimus in patients with tuberous sclerosis complex: final results from the EXIST-1 study. PLoS One 11:e0158476

137. Pierson TM, Yuan H, Marsh ED, Fuentes-Fajardo K, Adams DR, Markello T, Golas G, Simeonov DR, Holloman C, Tankovic A, Karamchandani MM, Schreiber JM, Mullikin JC, PhD for the NISC Comparative Sequencing Program, Tifft CJ, Toro C, Boerkoel CF, Traynelis SF, Gahl WA (2014) GRIN2A mutation and early-onset epileptic encephalopathy: personalized therapy with memantine. Ann Clin Transl Neurol 1(3):190-198

138. Kalappa BI, Soh H, Duignan KM, Furuya T, Edwards S, Tzingounis AV, Tzounopoulos T (2015) Potent KCNQ2/3-specific channel activator suppresses in vivo epileptic activity and prevents the development of tinnitus. J Neurosci 35(23):8829-8842

139. Riikonen R (1996) Long-term otucome of West syndrome: a study of adults with a history of infantile spasms. Epilepsia 37(4):367-372

140. Riikonen R (2020) Infantile spasms: outcome in clinical studies. Pediatr Neurol (20):30041-30042

141. Pies NJ, Beardsmore CW (2003) West \& West syndrome-a historical sketch about the eponymous doctor, his work and his family. Brain and Development 25(2):84-101

142. Strasser L, Downes M, Kung J, Cross JH, De Haan M (2018) Prevalence and risk factors for autism spectrum disorder in epilepsy: a systematic review and meta-analysis. Dev Med Child Neurol 60(1):19-29

143. Riikonen R, Amnell G (1981) Psychiatric disorders in children with earlier infantile spasms. Dev Med Child Neurol 23(6):747-760

144. Riikonen R (2001) Long-term outcome of patients with West syndrome. Brain and Development 23(7):683-687

145. Krijgh EJC, Catsman-Berrevoets CE, Neuteboom RF (2018) Early seizure freedom is a prognostic factor for survival in patients with West syndrome. Neuropediatrics 49(4):279-282. https://doi. org $/ 10.1055 / \mathrm{s}-0038-1654708$

146. Granström ML (2003) Prognosis of infantile spasms in: Jallon P. Esher J. Prognosis of epilepsies. John Libbey Eurotext, Surrey, U.K2003: 210-220

147. Riikonen R (1982) A long-term follow-up study of 214 children with the syndrome of infantile spasms. Neuropediatrics 13(1):14-23

148. Wong M (2013) A critical review of mTOR inhibitors and epilepsy: from basic science to clinical trials. Expert Rev Neurother 13: 657-669

149. GulMert G, Herguner MO, Incecik F, Altunbasak S, Sahan D, Unal I (2017) Risk factors affecting prognosis in infantile spasm. Int J Neurosci 127(11):1012-1018

Publisher's note Springer Nature remains neutral with regard to jurisdictional claims in published maps and institutional affiliations. 